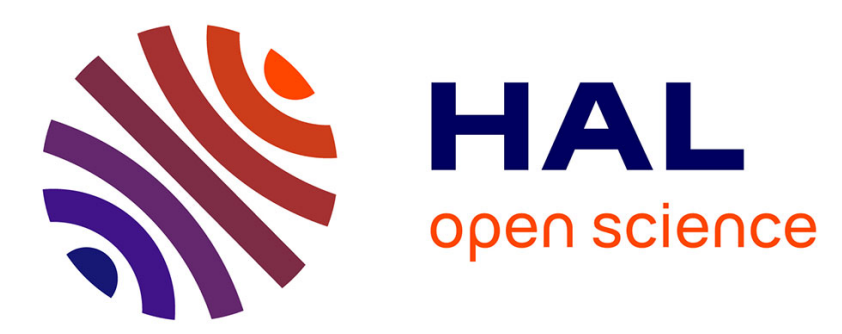

\title{
Romanian migration movements: networks as informal transnational organisations
}

\author{
Swanie Potot
}

\section{To cite this version:}

Swanie Potot. Romanian migration movements: networks as informal transnational organisations. Corrado Bonifazi, Marek Okolski, Jeannette Schoorl, Patrick Simon. International migration in Europe: new trends, new methods of analysis, Amsterdam University Press- IMISCOE Series, pp.87-106, 2008. halshs-00372743

\section{HAL Id: halshs-00372743 https://shs.hal.science/halshs-00372743}

Submitted on 2 Apr 2009

HAL is a multi-disciplinary open access archive for the deposit and dissemination of scientific research documents, whether they are published or not. The documents may come from teaching and research institutions in France or abroad, or from public or private research centers.
L'archive ouverte pluridisciplinaire HAL, est destinée au dépôt et à la diffusion de documents scientifiques de niveau recherche, publiés ou non, émanant des établissements d'enseignement et de recherche français ou étrangers, des laboratoires publics ou privés. 


\title{
ROMANIAN CIRCULATION: NETWORKS AS INFORMAL TRANSNATIONAL ORGANIZATIONS
}

\author{
Published in Corrado Bonifazi, Marek Okolski, Jeannette Schoorl, Patrick Simon, \\ International Migration in Europe.New trends and New Methods of Analysis, \\ Amsterdam University Press- IMISCOE, 2008, pp. 87-106
}

\section{Swanie Potot}

Since the Iron Curtain came down, the European continent has become, as it used to be, a vast space of exchange in which human migrations take diverse forms, from more or less permanent emigration to a variety of short-term movements, such as study programs or seasonal jobs (Okólski 2001). The kind of migration this text deals with consists of constant mobility, between the native country and several places abroad where migrants work on a temporary basis. This began at the beginning of the nineties and demonstrates how middleclass people from eastern European countries have played a role, without waiting for international agreements, in the construction of a large transnational space across Europe.

\section{Introduction}

The cases studied here concentrate on movements between Romania and several countries in the European Union (EU). Even if some aspects are similar to other eastern European countries, as regards migration the Romanian situation is quite specific. First of all, it should be noted that, unlike Poland, Hungary or Slovenia Romanians had to apply for a visa to visit any other European Union country until 2002. For years, one of the big points delaying the entry of the country into the EU has been its migratory potential and the supposed permeability of its frontiers (Michalon 2005). Indeed, Romanian migrants frighten western countries by their possible numbers and the supposed consequent burglary rate. Until the entry in the EU Romanians could not travel through EU countries for more than a three-month period and, apart from special bilateral agreements, were not allowed to work. Even if integration in the EU has occurred in 2007, during the last sixteen years, Romania has experienced a position of marginality in the international European area, which has strongly constrained, but not stopped, migrations.

The country's recent past and the way the transition to capitalism has been driven after the collapse of the communist regime have strongly weakened the national economy and, subsequently, reduced the standard of living of the entire population. Having become a communist country after World War II, from 1965 to 1989 Romania had to cope with a powerful dictatorship, harshly conducted by Nicolae Ceausescu. Thus, when in 1989, democracy was imposed, the economic situation was dramatic and national industry very weak, out-dated and unprepared for international competition. In such a context, the period of transition lasted more than ten years (many sectors are still restructuring towards privatization) and has had a very high social cost (Lhomel 2001).

Then, the option of working temporarily abroad has become a solution for coping with the difficulties encountered at home. The wealth gap between Romania and western countries allows migrants to make the most of their earnings by working in the West while spending in Romania. Thus, for most of them migration does not mean permanent leave; they actually 'settle in mobility', their life being divided between several places, but their single 'home'

\footnotetext{
* Swanie Potot, CNRS researcher, Unité de recherche Migrations et Société - URMIS, Email: potot@unice.fr
} 
remaining their original country (Morokvasic, Erel, Shinozaki \& Lenz 2003). At the beginning of the nineties, as the possibilities to travel toward the West were very few, informal (i.e. not legally organized) movements involved mainly young males in search of adventure as well as prosperity. They went for a few months to Germany, France or other countries with tourist visas (often bought on the black market in Romania) and found jobs there, mostly in construction or tourism (restaurants, hotels), where undeclared jobs are numerous (Diminescu 2003). These first experiences encouraged others to leave and, eventually, with the growing number of candidates, migrating has become easier, in particular through a large black market in Romania, selling visas, information, opportunities to work abroad, etc.

Acknowledging this situation, the research presented below, based on fieldworks conducted Romania, France, Spain and Great Britain, has tow main aims: first of all, to understand how a population who had no possibility to travel for decades, manage to create transnational spaces in which it can move and find opportunities to work at a European scale. Our hypothesis is that interpersonal links and limited mutual support have gradually created large social networks of working migration, very well adapted to the globalization of the European economy. This aspect will lead to pay close attention to the different kind of social links on which these networks are based. Secondly, we intend to enlighten the impact of these numerous micro strategies on the global Romanian society. We hypothesize that by bridging Eastern and Western Europe, migrants, as transnational actors, actively participate in the socalled "Romanian transition" toward a Western model.

\section{An ethnographic approach}

This survey began in 1998 and lasted for over five years, in the framework of a doctoral research (Potot 2003). Information and observations have been gathered in France on a regular basis during the period; in Romania, for around five months over several stays between 1999 and 2003; in the South of Spain, where two investigations were conducted in August 2000 and February-March 2001; and in London during a fieldwork of two month in 2001. As a whole, the diverse fieldworks concerned two independent migration networks.

First one has been increasing since 1995, between Târgoviste, a city of a hundred thousand inhabitants, in the area of Bucharest, and Nice, in the South of France. During this period, around three hundred migrants have traveled once or more between both places. Their main occupation in France consisted in selling newspapers on the street, an activity aimed at helping indigent people by giving them the opportunity to become street-sellers. When this opportunity disappeared while France had tighten its law ${ }^{1}$ concerning asylum seekers (Benattig and Brachet 1998) this model evolved into something much less synchronized: During a transition period, many little groups spread out towards Italy, Spain, Belgium, etc., in order to recover favorable conditions for temporary migration.

Eventually, in a third phase, another model emerged reducing notably the number of destinations chosen by migrants from Târgoviste. In fact, only migration toward London had important consequences for the network formerly established in Nice. The popularity of this destination relied on a few precious advantages: first of all, although getting into the country could be difficult, the British authorities did not go after undocumented persons very tenaciously and also, in such a situation, finding a place to work or renting a flat were quite easy compared to France; moreover, the job market was very dynamic and wide open to foreigners. Additionally, wages were clearly higher than in Southern Europe and, though

\footnotetext{
${ }^{1}$ Following the «Chevènement » law, from the 11th of June 1998, Romanian asylum seekers obtained a response to their application within a few days, so they could not use the administrative delay as a right to remain in the French territory for some months as they formerly did.
} 
everyday life was expensive, migrants managed to send more money back home. Still the main problem was to get there since Great Britain was not part of the Schengen Area ${ }^{2}$ and, subsequently, Romanians were obliged to apply for a British visa which was (and still is) difficult to obtain. A few migrants rapidly found a trick to bypass this barrier and, within a few months, the information being sold from one person to another had spread through the entire network. Then, travel becoming easier and the quality of life improving, migrants profil began to diversify: older people and women increasingly entered the migration process (Potot 2005).

This piece of fieldwork allowed to understand how the network re-constructed itself and widened as the job opportunities became more numerous and better than selling newspapers on the street. Actually, the survey highlighted the influence of legal, social and economic status upon migrants' collective behaviour.

After having made observations in both sites, fieldwork has been conducted in the homeland, not only to observe the living conditions before and after migration but also to compare the ideas and attitudes of migrants when they are abroad and when they are at home.

The second migratory course studied was totally independent from the first. It emerged between a region called Teleorman, in the south of Romania, and the province of Almeria, more precisely in the area of El Ejido, in Spanish Andalusia.

This area is famous for developing its agrarian economy by harshly exploiting the labour of many foreign workers; even often undocumented ones. Many nationalities are represented there (Filipinos, South Americans, Sub-Saharan Africans, etc.) but the larger and oldest group come from Morocco, ${ }^{3}$ and is subject to considerable racism. In such a context, in February 2000, for three days, racial tensions exploded into riots against Moroccan workers. Following these riots, all Moroccan workers went on strike, paralysing farming activities. At those times, journalists exposed the employers' manoeuvres: they immediately hired some Eastern European migrants, mostly Romanians, to replace the Moroccan strikers ${ }^{4}$.

By conducting fieldwork on the spot, it has been possible to conclude that, even if the environment was different from the circulation of the Târgoviste-Nice-London network, the presence of Romanians in this Spanish province was part of the same migration phenomenon, which tends to develop in different European economic and spatial areas. A main feature is that it involves people originating from the same area in Romania, connected either directly or through third persons and thus sharing local know-how, who manage to find sectors of employment where their presence is accepted. Because of the poor wages and job conditions offered, they are not in direct competition with national workers. Moreover, being "strike breakers", as the media put it, allowed them to enter a niche of employment (Waldinger 1994) previously occupied by other foreigners.

Compared with the migrant population from Târgoviste, this one was more diversified; composed of younger persons as well as of older ones; some retired who had come there to make up for the small pensions they received in Romania. Some migrants were unemployed in Romania, as is often the case for young and educated people, but others had left their rural or urban jobs at home to earn much more money within a few months, working hard in

\footnotetext{
${ }^{2}$ Schengen agreements, which allow the free movement of persons within its area, have been signed by Germany, Belgium, Holland, Luxemburg, Spain, France, Portugal, Italy, Greece, Austria, Denmark, Norway, Finland, Sweden and Iceland.

${ }^{3}$ In 2001, Moroccans were estimated at around 25,000 workers (legally present) in the province of Almeria, while others nationalities were practically absent from official data.

${ }^{4}$ See the article by Juan Goytisolo and Sami Naïr, "Racisme en Espagne", Le Monde (02.15.2000) or El Pais (02.10.2000), "El revelo de magrebies por europeos del Este reaviva la tension en El Ejido", p.1.
} 
Spanish agriculture. In the greenhouses, the presence of quite a few Romanian girls was also noticeable as they were nearly the only women hired.

Lastly, fieldwork in the Romanian region of origin was conducted in cities and small villages $^{5}$. Vast amount of information had been gathered through interviews with migrants and their families and interviews with town councillors, priests and local government officials. The importance of inter-individual connections for migrating was obvious: those who wanted to leave and did not attain their goal or those who had returned without having earned any money in Spain, always blamed the lack of acquaintances. In contrast, flourishing families, who were constructing big houses, had often sent several members of the family, who could rely on each other and replace each other in the Spanish province or elsewhere. Thus, it was possible to see traces of these migrations in the landscape: many houses erected in small villages showed how wealthy the region had suddenly become.

The aim here is not to compare both networks in every aspect but to point at recurrent aspects occurring in both, in order to understand from an anthropological point of view how Romanian migrants, who were non-existent until 1989, have been able, within a few years, to develop original collective strategies and new emigration modalities.

\section{Transnational migration network, a social form adapted to "globalised" Europe}

These two case studies analyze informal migrant networks. The point is to show how these informal organisations are being constructed through migrant practices, on the basis of diverse links, and how they find a way, throughout Europe, to penetrate niches open to illegal workers and which have spread across the western part of the continent. An analysis of Romanian movements brings to the fore the capacity of these transnational organisations: they deal with the paradox of a rigid legislative frame regulating conditions of entry into the European area and the needs of an economy that go beyond any notion of state borders. Thanks to many social links - even if these are sometimes weak links (Granovetter 1973) - maintained over very large areas, migrants manage to bypass border controls and policies restricting migrations and to spread within areas of very different geographic, social and economic characteristics. In fact, as the fieldwork shows, each migration destination is specific, and migrants continue to adapt themselves to each of them, as variations in the economic and political situation in Europe regularly cause them to leave one place and find a new one where they might be accepted as workers. Thus, the 'uprooting' these migrants experience, goes hand-in-hand with the permanent re-composition of circulation areas, subject to an international situation simultaneously driven by the global economy and the internal workings of the different States.

\subsection{Network sociability and structural constraints}

This capacity of migrant networks relies on the kind of sociability operating in these organisations. Links between migrants may be strong within very small groups even if weak between groups or between other individuals, so the social constraint experienced by migrants is quite trivial. Thus, they usually feel free to act as they intend to during their migration and are not obliged to conform to the model used by others: for example in Nice, a few people refused to sell newspapers on the street, as they did not find it worthwhile, others chose to rent flats far away from inner city hotels where most of their compatriots lived, but they

\footnotetext{
${ }^{5}$ This study has been conducted with a team of the University of Bucarest, under the tutorship of Professor D.Sandu.
} 
maintained close connections with other migrants from Târgoviste and could request their collaboration or assistance if needed. ${ }^{6}$ On this point, these networks differ from other migrant communities who exercise strict control on their members' activities abroad (see for example migrant Mourid communities (Salem 1981)). Here, members' participation in collective activities is variable and fluctuating. People can be more or less integrated into the network, participate irregularly and even sometimes dissociate from other members before joining in once again. As long as they do not act against the network, for example by undermining relations with an important employer or by misbehaving in a hotel where many people from the same area are accommodated, the network remains open to its members, even occasional ones.

Consequently, migrants attempting to find original migratory destinations do not experience new migratory paths collectively, but individually or in very small groups. They sometimes indulge in taking risks, but this does not challenge the position set up by the entire network. Meanwhile, failures or discoveries that cannot be shared with many people may still be exploited by a few. Thus, two boys who were formerly in Nice decided to go to Madrid to work. After a few months and many difficulties, they managed to find jobs in a restaurant and to settle down but they were not able to help their compatriots in reaching the place or in being hired. So, they added a destination that was not part of their network's area, but it never became a collective migration spot. However, these two boys keep contact with their counterparts living in France or in England and so become a resource that could be exploited in the future. The possibilities of finding new opportunities are thus multiplied by attempting new strategies. After such a discovery, the most relevant pieces of information spread little by little, first between men close to the "discoverer", and then among an increasingly larger population, until most members of the network are informed. To sum up, the fact that individuals are connected by loose links makes it possible for each person to take original initiatives that, when successful, will then be used by the whole group. Indeed, the strength of a migrant network comes from combining individual initiatives and sharing resources. Therefore, the amount of knowledge and abilities shared in a network is constantly increasing, allowing migrants to discover how to filter collectively into societies where they do not have any legal means of access.

The Romanian migrant network may then be thought of as a loose form of social organisation, especially tailored for transnational mobility. We therefore observe that the transnational movements of these migrants rely on the interpretation of each State's activities as regards border and immigration controls (Portes 2001). Laws are not the only aspect taken into account by migrants: they also consider how each State's institutions and authorities act in the face of illegal migration. With the same legal situation, a State, or a special area within a State, might be more tolerant toward undocumented workers if their labour is required by a particular economic sector, as in the province of Almeria where police leave undocumented people in peace if they can prove that they regularly work in greenhouses. This kind of information is very precious as it determines the possibility of identifying a suitable destination for a group. But the only way to learn about it is through oral knowledge passing from one migrant to another, even if he/she is not member of the network. In this sense, one can say that the migrant network adapts to the way in which international migration is treated by the States: the degree to which States implement controls but also aspects that go beyond the law, namely the demand for labour.

Consequently, in order to find new migration channels and destinations, migrants do not study international law to find out where they might work legally, but rather they deal with

\footnotetext{
${ }^{6}$ For example, migrants could collaborate to buy a car they would use at different moments of the week or to engage in a construction task they could not realize on their own. Assistance may also consist in giving administrative information or in translating documents, etc.
} 
their future employers, on the basis of what they have heard or what they believe.

Nevertheless, the cases studied tend to show that this trend towards ignoring the legal framework is limited; mobility practices tend to harmonise, in a certain way, with decisions taken at the international level. For example, Târgoviste's network reorientation from Nice to London happened just after the law concerning the asylum process in France was tightened. Their departure was therefore in response to new national legislation; yet migrants did not try to obtain legal status nor did they stop travelling. Rather, they looked for another place where they would be tolerated and could remain unnoticed. It appears clearly here that, although those people do not directly conform to national or European policies, their movements partly depend on the enforcement of the law. In concrete terms, these statements show that what is important in migrant orientation is neither a country's or the EU's law or policies concerning the movements of persons, but institutional and employer practices. The cases studied in Spain are examples of this tendency: Romanian migrants found a socio-economic niche welcoming them for their economic role, and where they would not be very strictly controlled by the police, in spite of the fact that this country is part of the Schengen Area, and therefore subject to strict legislation concerning immigration. Consequently, even if official policies managing flows do not weigh heavily upon transnational migration, what the State actually does in practice will influence transnational migration routes. Thus, states influence transnational migrant activities through the implementation of public policies.

Moreover, we observe that despite the efforts of the European Union to harmonise policies concerning migration and asylum within its boundaries, local disparities in the way migration is dealt with are maintained. As national borders inside the European area are progressively fading, measures taken in the face of migration are multiple and depend very much on the place where the migrants are. With the same legal framework, different authorities have different attitudes towards foreign workers, sometimes even within national areas. For example, in contrast with the tolerance shown by authorities in southern Spain, provinces very close to Almeria apply the law strictly, preventing any illegal work and expelling undocumented people. So, migrants do not dare travel through Spain, as they know that they cannot count on the tolerance of the police encountered in the province of Almeria and they might be caught and expelled. Thus, by their various attitudes, local authorities delineate new territorial borders, inside the national territory.

Yet, if networks manage to submit to these implicit directives without erring, it is above all thanks to how well the networks functioning. Actually, nobody knows globally and precisely how the situation evolves in Europe; there is no deciphering of the evolution of zones of tolerance. The ability to adapt and to evolve from one place to another is, from this point of view, a collective competence. Individuals inside networks explore several migration possibilities among which only a small number is collectively useful. Only the most favourable situations, that is to say the ones providing improvement, are collectively invested in. The situation of each migrant trying a new destination is known by the other members of the network, and they will move to that place only if it offers better prospects than the previous one. However, the suitability of an option does not depend only on the economic benefits migrants may expect; living conditions and notably the fear of being expelled at any moment are very important too. Sharing information inside networks more or less allows the migrant group to choose between possible migration situations, but at the expense of strong social and/or institutional pressure, and situations in which undocumented workers are economically coveted and tolerated by the local society. For example, when migrants from Nice were looking for a new place to go, two of them went to Madrid, where they stayed, but the numerous difficulties they encountered there discouraged others from joining them. In this sense, the network helps in orientating migrants toward areas in which States unofficially authorise immigration. 
Hence, this organisation increases the flexibility imposed on undocumented workers while the transnational network makes it possible to fulfil this demand. When a network is spread over more than a single working niche, migrant workers are more flexible when dealing with employers. Inside a network, several activities and destinations are often exploited; this makes it possible for its members to evolve from one job to another, or from one destination to another, at a low financial, time and psychological cost. Thus, when employers try to lay off some of their workers, for example during the farming low seasons, or if the tourist industry slumps, moving on to a new place to work is made easier by collective organisation. The same applies when, due to political decisions, the government appears to be less tolerant of the presence of illegal migrants. In this case, migrants maintain their social invisibility by leaving a destination or a work niche when their presence is not wanted anymore. This suits employers who require a very flexible working population and who do not want to spark a conflict when, in case of difficulties; they decide to reduce their manpower or to cut wages. For the migrants studied, the way to prevent a deterioration of their working condition is to keep moving, just as they first left home when their standards of living worsened.

\subsection{Weak collective identification}

The trend to submit to or even to anticipate constraints of invisibility and flexibility can be connected with another aspect of migrant networks. Differing from communities who clearly identify their members through traits thought to be commonly shared, in the networks studied, a collective identity never clearly appeared. When individuals use an identifying "us", it is never an intrinsic definition but is used simply to differentiate themselves from the other groups encountered in the area of migration (Barth 1969). The fact of belonging to a 'Romanian group' or to 'a Romanian migrant group of workers' is claimed only when migrants clearly identify a population category they want to be distinguished from. For example, Romanian Roma, greatly stigmatised by the main population in Romania, represents a real threat to the other Romanian migrants' identity. This is because western societies often think of Romanian migrations as being a Roma activity, as a result of which middle-class Romanians might then be regarded abroad as being Roma. The violent racism toward this minority in Romania is even stronger in migration situations.

However, we observe that this xenophobia, which sprang up in Romania concerning a specific ethnic group, the Roma, has been transferred abroad as it is, and concerns new ethnic categories. Dirtiness and treachery which are, in the xenophobic discourse, characteristics of Roma, have become traits distinguishing North Africans in Spain or Pakistanis and Indians in London from Romanian migrants. Surprisingly, during the inquiries Romanian migrants explained that Moroccans would always remain on the margins as they had been nomadic before their arrival in Spain, like the Roma were in Romania, while this interpretation was erroneous and previously unheard of. This assertion shows how a stigma can apply to one population and then to another without being re-considered by those using it. When Romanians live abroad, they consider themselves as middle-class Europeans and claim their proximity to the dominant national population of their destination by differentiating themselves from socially lower foreign workers, often coming from former colonies or southern countries. The reference to the "Romanian nation" has only one aim, to distinguish themselves from any 'racial' categories, definitely seen as socially inferior. Thus, rejecting the "others" is the main foundation of a collective "us" used by migrants.

Moreover, in the various studies, references to the 'community' of migrants were almost non-existent: although migrants were bonded by links and met each other occasionally, there were no places, such as churches, or special events which would gather all Romanians present in the area. In addition, although a few people were more popular than others, there was no 
figure representing authority or centralising information and demands in the network. During interviews, Romanian migrants would always reject the idea of a community, each one making it clear that they did not know all their compatriots present there and felt no obligation of solidarity towards them.

But if no claims are made to belonging to a national group during migration abroad, when back in Romania, migrants give another, much closer and more unified, image of their group. Former migrants regularly meet in bars or discotheques and are proud to show the people around that they have all come back from the West where they have had the privilege to work. At home, this loose organisation becomes a social group that plays an important but discreet part in the Romanian transformation process.

\section{Migrants in the transition process}

As said before, these movements cannot be considered simply as emigration. Most migrants divide their time between some periods abroad and others in Romania, where they maintain their social links and participate in economic and social life. These migrants can be seen as a bond between Eastern and Western Europe. To some extent, they play a special role in Romania as transnational actors. They participate in the reshaping of the economic and social post-communist environment. It seems that repeated contacts with other countries are encouraging the emergence of a new state of mind, due to the partial acculturation to a Western capitalist model that Romania intends to adopt.

\subsection{Upon returning, western consumerism}

It is noticeable that when they come back to Romania, migrants do not live in the same way as they did before they left: migration aims, whatever individual plans may be, at improving living conditions in Romania. Exceptionally, insufficiently skilled migrants, or those who cannot rely on acquaintances to facilitate their period abroad, return home without any savings, meaning that they have failed. In order to demonstrate to everybody that this is not their case, most of the people who return from abroad show off their wealth; improved social status has to be shown. This is why, in departure zones, migration is above all a visible phenomenon, in clear contrast with the habits of the stay-at-home people (i.e. those who have never left the country), consumption becomes ostentatious and one can notice, in the streets, young men dressed as westerners (Levi's, Nike trainers, etc.) or driving elegant French or German cars. Also, they do not hesitate to buy all kinds of food, even in expensive shops, and to throw it away if they do not want it any more. This behaviour of endless spending -which has nothing specific to the Romanian migration case (Sayad 1991), is therefore very different from the thrifty habits which have been developing for a long time in Romania in the face of a difficult economic situation.

In town, the most visible aspect of migrants spending their money is, without a doubt, their presence in the many "chilling-out" places. Fashionable bars and discos are the places where people coming back from abroad meet up with each other. Migrants' "headquarters" are the most westernised locations. Of course, they are not the only people patronising these establishments, but the presence of migrants is noticeable in that they are regular customers and they specifically prefer to consume expensive imported items: Belgian or French beers, American cigarettes, crisps and so on. During a party, members of the group will pay for everybody at least once or twice, without counting the cost, as if their resources were unlimited. Their earnings abroad partly explain this, but they are often much lower than what migrants claim and these parties make a substantial hole in the budgets of these young people. 
However, they must spend lavishly in order to create a special image of the group and precisely, to mark the difference from the stay-at-home people who often cut down on leisure expenses and concentrate on more important needs.

In this sense, migrants use consumption to win social points: a migrant does not spend in order to live comfortably; he consumes leisure in order to provide evidence of his new social belonging. This phenomenon is obvious in the attitude of urban migrants, who cannot easily build themselves a house and yet invest very much in ephemera: they spend on leisure, clothes, food... all items not so precious in themselves but which giving prestige to those who buy them.

In the same way, goods distribution networks also play a part in the creation of a social image. As explained above, the Romanian black market is very important and many households rely on it for everyday supplies such as food and clothes (Duchêne, Albu and Kim 2002). Even if they do not completely abandon it when they return, migrants want to show that they do not need the black market to live. For example, most of them avoid purchasing any items in the market squares because they are too "folksy" for them. Very often, when they come back, they prefer to buy items in a 'western way', in modern self-service stores rather than in little shops in their area. During the observations conducted in Târgoviste, the BP petrol station that had replaced the old Peco station (the former national petroleum company) had opened a mini-supermarket, which had become an important place for migrants to shop and even to meet. Of course, the mini-supermarket attracted many onlookers too; but no one consumed as much as migrants who, pretending they would find there the western quality items they were accustomed to, considered the store as their main shop. Later on, the Carrefour supermarket which opened in Bucharest also became a major point of reference in the migrant universe. To visit these places is a way of appropriating the western consumer way, and then, to make it visible that one belongs not only to a relatively rich social class, but to a western culture too. It is clear that this behaviour is conscious: the point in acting in this way is not mainly to preserve habits acquired in the West, as their standard of life was by no means as good while they were abroad, but to achieve a higher social status in Romania.

Yet, the introduction of a consumption pattern favouring the formal market, to the detriment of the black market, contributes to changing Romania into a country where consumption follows the Western pattern. While the black market has constantly been reinforced for several decades, migrants introduce within the middle class new habits of consumption which invert the trend. Without a doubt, the fact that an important part of migration income is put back into the official economy supports the economic and official development of the country. In this sense, migration contributes to the emergence of new attitudes tending to develop a consumption mode typical of capitalist middle classes.

Although the most visible aspect of the migration phenomenon in Romania is high consumption, migrants contribute to the transition by other means as well.

\subsection{Migrants and delocalisation}

Experience abroad allowed migrants to be part, even if in a marginal way, of a productive model quite distant from the one developed during the decades of the so-called communist dictatorship. During those times, many factories would often run very slowly, raw materials were often missing and, as unemployment was forbidden, workers used to be far too numerous for the work to be done. Moreover, stealing from the factories was quite common; it was a way of compensating for low wages and the absence of items in shops. After the collapse of the communist regime, these habits remained in many places and contributed to slowing down the transition process. So, working in the western economy required a very different attitude to work. In the diverse sectors where they found jobs in the West, Romanian 
workers had to be especially productive if they wanted to keep their job in the face of competition from other migrants. Compared with what they previously earned in Romania, the high wages they could expect for their jobs encouraged migrants to accept hard working conditions, and they rapidly understood that involvement in the success of the firm they worked in was required from them. They then learnt to manage relations with their employers and with their bosses in order to conform to the image of the foreign pliable and not very vindictive worker.

Since then, the migrants' experience abroad allows them to contribute, in an efficient way, to the shaping of new behaviour at work. This becomes very evident in the part they play in western firms wanting to relocate in Romania to find less expensive manpower. For example, a young woman who used to work as an employee in a shoe factory in Milan, had been hired for managing human resources in a factory of the same firm that had opened in Timisoara. Her duty was to liaise between Italian bosses and Romanian employees. She was there to make it clear that the payment of high wages was in return for a constructive attitude towards the company, being on time, not stealing and more generally, being 'productive' at work. Here, familiarity with another operating mode helps to transform 'communist' workers into 'capitalist' workers.

In other cases, migrants recruited by these foreign firms help them in their dealings with Romanian institutions: not only do they often speak foreign languages, but also the Romanian administration is still quite complicated and foreign employers require help. Thus, migrants who both understand western employers' expectations and know how to deal with Romanian State officials can sell their services to these foreign enterprises. In a certain way, their transnational culture may allow migrants to be a link between the two worlds, and hence to transfer foreign requirements to the post-communist environment.

\subsection{Migrant contractors}

Another way of participating in the transition consists, in Romania, in developing a capitalist spirit turned to entrepreneurship. Some migrants take advantage of their - relative wealth and of their migration know-how in order to start small businesses in their homeland.

Often, they are in the import-export trade and make direct use of migrants' journeys abroad. This is the case for example of many second-hand clothes shops, with stock imported from Germany or from France. The migrant often has a partner - usually a family member who takes care of the store in Romania while he deals with sellers abroad. These businesses represent a second investment in migration: most of the time, migrants have not been abroad in order to make business contacts, it is only when they come back home that they decide to utilise their connections. Then, a few migrants become specialised in the import business and will, in a second phase, travel especially for this purpose. The procedure is the same for small export firms: a former casual farm worker in Spanish greenhouses turned, for example, to making terracotta pots in Romania, which he sells to his Spanish former employer.

But migration earnings may be invested in firms which focus only on Romania. In the city of Târgoviste, the most fashionable bars belong to former migrants now settled in Romania. The western style of their establishment attracts many migrants during their visits to Romania. Others start photocopy service shops for example. In all of these cases, the migration experience clearly appears, above all, as a way of financing these enterprises. But one can suppose as well that the energy and resourcefulness developed during migration are also reinvested into these small firms. During their migratory experiences, migrants learn to take risks, to find information about the places they could go, to negotiate with state authorities and to use every opportunity to find a place in the West in spite of difficulties due to their 
status. Hence, it seems that 'wangling', developed when facing economic difficulties at home, may turn into a useful business skill, thanks to the experience abroad.

Moreover, the migratory experience and the fact of belonging to a migrant group in Romania help businessmen as they can rely on their migrant counterparts for a partnership. As it has already been pointed out, being a migrant implies participating, in Romania as well, to a network of former and future migrants. Hence, returning migrants may expect cooperation from their peers, with whom they share this 'migration culture' and an amount of capital to be invested. Thus they may find, in their social group in Romania, possible partners in order to launch into business. It appears clearly here that migration provides more than economic capital: it makes social capital available for former migrants (Bourdieu 1985) allowing them to participate more actively in local economic life. In a way, even if many of these small enterprises often have a short lifespan, this small-scale economy, sustained by small investors, contributes to the improvement of Romanians' standard of living.

\section{Conclusion}

Thus, transnational migrants take part in the creation of a new social stratum in Romania which, materially and culturally, tends to move away from the ancient 'communist' habitus (Bourdieu 1980) to move closer to the western middle-class state of mind. Being 'crossEuropean' gives them a special position both in the West and in their homeland. Through transnational networks, migrants participate simultaneously in two different economic processes: one in Western Europe and the other in their homeland. In the West, their role as underpaid workers contributes to organising new forms of global capitalism (Réa 2002) while, in their own country, these migrants are directly involved in the so-called transition process which aims to put Romania into the spectrum of the industrialised countries.

Thus, network is the structure by which migration recurs: As Waldinger (1994) puts it, information concerning a particular destination circulates inside this organisation, thus favouring the repetition of a first experience. However, for migration circulation studied here, the fundamental role of the network appears clearly to lie in teaching each person migration 'skills' which is made possible by meeting more experienced peers. New migrants can thus rapidly learn migration know-how, which allows them to become self-sufficient and to participate personally in developing new occupations in the network. The main asset is the ambivalence of these abilities, improved by each individual and transferable to different migration situations. As the working opportunities that these migrants exploit in the West are very fragile, resources provided by migrant networks do not consist mainly in reinforcing their position in niches in which they do not have any power. What is usually passed on inside these fluctuating informal organisations is the capacity of moving around inside the European area and the ability to re-orientate and adapt to a new environment. Hence, not only do these organisations favour the enlargement of a group in a specific place; but they also contribute to the improvement of the transnational circulation itself.

In such a context, close attention paid to this transnational migrations bring to consider these networks as 'informal organisations' which have their proper recurrent functioning. Relying on diverse interests and type of social links, there are flexible, dynamics and spread over large territory. These patterns fit very well with the requirements of the globalization process: migrants have then the capacity to move from one spot to another adapting to the amount of activity on real time and avoiding, by doing so, to enter into conflict with their employers or local populations when their presence is not required any more. 


\section{References}

Barth, Frederick (1969), Ethnic groups and boundaries. The social organization of culture difference. Oslo: Universitetsforlaget.

Benattig, R. \& O. Brachet (1998) Les dynamiques migratoires roumaines, le cas des demandeurs d'asile en France. Direction Population et Migrations.

Bourdieu, Pierre (1980), Le sens pratique. Paris: Les éditions de minuit.

Bourdieu, Pierre (1985), 'The forms of capital' in J.G.Richardson (ed.), Handbook of Theory and Research for the Sociology of Education, 241-258. New York: Greenwood.

Diminescu, Dana (ed.) (2003) Visibles mais peu nombreux. Les circulations migratoires roumaines. Paris: Maison des Sciences de l'Homme.

Duchêne, Gérard., L.L Albu, \& B.Y Kim (2002), “An attempt to estimate the size of informal economy based on household behaviour modeling". Romanian Journal of Economic forecasting 1:17-24.

Granovetter, Mark (1973), 'The Strength of Weak Ties', American Journal of Sociology 78:1360-1380.

Lhomel, Edith (2001) 'Roumanie 2000-2001. Un nouveau départ?' Le courrier des pays de l'Est 1016:164-177.

Marcus, George E. (1995) 'Ethnography in/of the World System: the Emergence of MultiSited Ethnography'. Annual Review of Anthropology 24:95-117.

Michalon, Bénédicte (2005), 'Dynamiques frontalières et nouvelles migrations internationales en roumanie', Revue d'études comparatives Est-Ouest 36:43-69.

Morokvasic, Mirjana, Umut Erel, Kyoko Shinozaki, \& Ilse Lenz (2003), Crossing borders and shifting boundaries. Opladen: Leske + Budrich.

Okólski, Marek (2001), 'The transformation of spatial mobility and new forms of International population movements: Incomplete migration in Central and Eastern Europe', in J.W. Dacyl (ed.) Challenges of Cultural Diversity in Europe, Stockholm: CEIFO.

Portes, Alejandro. (2001), 'Introduction: the debates and significance of immigrant transnationalism', Global Networks 1.

Potot, Swanie (2003), 'Circulation et réseaux de migrants roumains: une contribution à l'étude des nouvelles mobilités' Thèse de doctorat, Nice: Université de Nice Sopia Antipolis.

Potot, Swanie (2005), 'La place des femmes dans les réseaux migrants roumains", Revue européenne des migrations internationales 21:243-257.

Réa, Andréa (2002), 'Le travail des sans-papiers et la citoyenneté domestique' in M.Péraldi (ed.) La fin des norias? Réseaux migrants dans les économies marchandes en Méditerranée, 450-478. Paris: Maisonneuve et Larose, MMSH.

Salem, Gérard (1981), 'De la brousse au Boul'Mich: le système commercial des mourides en France', Cahiers d'Études Africaines, XXI:267-288.

Sayad, Abdelmalek (1991), 'Elghorba: le mécanisme de reproduction de l'émigration' in A.Sayad (ed.), L'immigration ou les paradoxes de l'altérité, 23-48. Bruxelles: De BoeckWesmael. 
Waldinger, Roger David (1994), 'The making of an immigrant niche', International Migration Review 8:3-30. 